\title{
35. NEOGENE EVOLUTION OF CANARY ISLAND VOLCANISM INFERRED FROM ASH LAYERS AND VOLCANICLASTIC SANDSTONES OF DSDP SITE 397 (LEG 47A)
}

\author{
Hans-Ulrich Schmincke, Institut Mineralogie der Ruhr-Universität, D 463 Bochum, Federal Republic of Germany \\ and \\ Ulrich von Rad, Bundesanstalt für Geowissenschaften und Rohstoffe (Federal Geological Survey), \\ D 3000 Hannover, Federal Republic of Germany
}

\begin{abstract}
Miocene to Pleistocene volcaniclastic sediments were analyzed from Holes 397 and 397A, northwest of Cape Bojador (Northwest Africa) and south of the Canary Islands. These sediments are of two types: (1) ash-fall deposits of silicic and alkalic (trachytic-phonolitic-rhyolitic) composition, and (2) deposits of submarine volcaniclastic mass flows (debris flows, turbidity currents) of basaltic composition.

Air-fall ash layers (mostly 0.5 to $5 \mathrm{~cm}$ thick) occur at about 19 m.y.B.P. but most are found in sediments ranging from about 14 to $0.3 \mathrm{~m} . \mathrm{y}$. They consist of colorless to brown tricuspate and pumice shards, feldspar, and mafic phenocrysts, and small felsic rock fragments. Refractive indexes of about 1.52 to 1.54 suggest rhyolitic to phonolitic compositions. Glass is replaced by palagonite, clay minerals, zeolites etc. in rocks older than about 14 m.y., while the younger shards probably all have been hydrated and chemically changed to some degree. Some ash layers are completely zeolitized (phillipsite, clinoptilolite).

Two middle Miocene volcaniclastic sandstones, a lower 7.8-meter-thick turbidite (V-3) and an upper 4.5-meter-thick debris flow $(\mathrm{V}-1)$, are indistinctly graded. The rocks of flow $\mathrm{V}-3$ are fine to medium sand-sized hyaloclastites with dense to moderately vesicular, palagonitized "sideromelane" shards, minor igneous rock fragments (microgabbro, basalt, tachylite), and small amounts of nonvolcanic rock fragments, detrital quartz, and biogenic debris. The matrix is dominated by clay minerals (smectite) with minor admixtures of carbonate and zeolite (analcime). V-4 is a 20 to 30 meter thick early Miocene hyaloclastite-rich sandstone.

The upper unit (V-1) is very poorly sorted and coarse grained. It consists chiefly of rounded to angular, generally non-vesicular tachylite to fully crystallized basalt and trachyandesitic rock fragments. Admixtures are trachyte, microgabbro, highly vesicular basaltic pumice shards (now replaced by clay and carbonate), and minor non-volcanic clastic and biogenic debris. The partly recrystallized matrix consists of brown clay and, less commonly, carbonate. Clinopyroxene (titanaugite) is common as phenocrysts in the rock fragments and as single crystals; clinopyroxene shows only minor replacement. Olivine, next in abundance, is always replaced by layered silicates or carbonate. Plagioclase is the most common groundmass constituent of the rock fragments and is mostly albitized or replaced by clay minerals.

Mineral composition (Ti-augite!) and paragenesis show that alkali basalts and related derivative rock types typical of the volcanic rocks of the Canary Islands are the dominant or only source rock for the igneous components. Good rounding, oxidation textures in olivine, and a high ratio of crystalline relative to tachylitic and glassy basaltic fragments indicate that most or all volcanic fragments in the sandstone of the upper flow (V-1) are of subaerial, epiclastic derivation. Age and mineralogical composition of rock fragments strongly suggest derivation from the eastern (Fuerteventura) rather than central (Gran Canaria) Canary Islands. The older (ca. 19 m.y.B.P.) ash fall might have been supplied by
\end{abstract}


trachytic volcanoes from Fuerteventura or Lanzarote; those around 14 to 9 and 4 m.y.B.P. may be from Gran Canaria; while the younger ash-fall deposits may be due to explosive eruptions on the western Canary Islands, most likely Tenerife.

The stratigraphic distribution of the different types of volcaniclastics reflects the emergence of the Canary Islands in general and that of Fuerteventura in particular. Volcanic activity is most intense during the shield-building stage; the mass flow deposits are thought to be the result of (a) the submarine shield stage (unit V-3: moderate to shallow water depth, possibly with subaerial detritus from uplifted emergent plutonic and Cretaceous sedimentary rocks), and (b) the subaerial shield-building stage of Fuerteventura between about 16 to 17 m.y.B.P. (unit V-1: subaerial erosional detritus and tachylite from lavas advancing into the sea). Volcanic episodes following the shield-building stages were much less voluminous on all of the Canary Islands, although development of highly differentiated magmas resulted in abundant explosive activity producing numerous ash layers particularly during the middle to late Miocene ( 14 to 9 m.y.), early Pliocene ( 4 m.y.), and late Pliocene to Pleistocene ( 3.3 to 0.3 m.y.B.P.).

\section{INTRODUCTION}

During Leg 47A (March/April 1976), two holes (397 and 397A) were drilled on the uppermost continental rise, 100 to $150 \mathrm{~km}$ south of the Canary Islands and $100 \mathrm{~km}$ northwest of Cape Bojador (northwest Africa) at $26^{\circ} 50.7^{\prime} \mathrm{N}, 15^{\circ} 10.8^{\prime} \mathrm{W}$, and 2900 meters water depth (Figure 1). At Site 397, 1300 meters of Neogene sediments underlain by 153 meters of Lower Cretaceous rocks (Figure 2) were penetrated. About 15 ashfall layers were recognized in the lower Miocene to Pleistocene sediments, and several submarine volcaniclastic debris flow deposits were encountered in middle Miocene rocks. It is highly suggestive that these volcanogenic sedimentary rocks are related to volcanic activity on the nearby Canary Islands. Moreover, such distinct layers could possibly reflect well-known and dated volcanic events on the Canaries and perhaps even reflect different stages in the volcanic evolution of a single island or the entire island group.

In this paper, we will present some petrographic data and tentative interpretations on the volcaniclastic debris flow deposits and brief information on the ash fall layers. Altogether, 36 samples were selected for smear-slide, coarse fraction, thin-section, and X-ray diffraction (XRD) analysis (Table 1 ). We are presently preparing a more detailed account comparing all ash layers from the nearby DSDP Sites 368 and 396 (Leg 41; see also Rothe and Koch, 1978) with those from Site 397 and with the record from the Canary Islands.

\section{STRATIGRAPHIC AND REGIONAL SETTING}

Figure 2 shows the stratigraphic setting of the observed ash-fall layers and volcaniclastic sandstones. Except for two $19.3 \mathrm{~m}$.y.-old altered vitric ash layers (Section 397A-23-3, early Miocene), all ash-fall layers occur in the late middle Miocene (14 m.y.B.P.) to Pleistocene (0.3 m.y.B.P.) section of Hole $397 .^{\prime}$ Most ashes

\footnotetext{
${ }^{1}$ The age control of these volcanic events is interpolated and tied into the nannofossil biostratigraphy (Čepek and Wind, this volume) and the equivalent absolute age scale by Martini (1976, Table 1).
}

are discrete layers, a few $\mathrm{mm}$ to $\mathrm{cm}$ thick, whereas traces ( $<5 \%$ of the $>63 \mu \mathrm{m}$ fraction) of disseminated volcanic material have been found in the coarse fraction of many upper Neogene samples (see Site Report, this volume; Diester-Haass, this volume).

Burrowing organisms have caused extensive mixing of air-fall ashes with the overlying sediments, as shown by X-radiographs (F. McCoy, personal communication). Four to five volcaniclastic debris flow units ("lithofacies F-4B," see Site Report) have been identified in the lower middle Miocene (16.5 to 17.6 m.y.B.P.) section. They have been numbered from V-1a to V-4 (Figure 2). V-la is actually a pebbly mudstone containing only about 5 per cent of volcanic rock fragments ("lithofacies F-4A," see Site Report). Two of the debris flows (V-1 and V-3) are several meters thick (Table 1, Plates 1 through 3). Because of their greater density (GRAPE density: 2.1 to 2.5 ) and sonic velocity (V-1: 2.8 to $3 \mathrm{~km} / \mathrm{sec} ; \mathrm{V}-3: 2.5 \mathrm{~km} / \mathrm{sec}$ ), they form strong seismic reflectors and obstacles to drilling. Especially reflector R-8 (at about $810 \mathrm{~m}$ sub-bottom) appears to be caused by volcaniclastic debris flow V-3 (Figure 2; see also Wissmann, this volume). Before drilling this site, the reflectors R-7 and R-8 were thought to represent Eocene cherts ("Horizon A") and/or Oligocene or older Paleogene unconformities. Reflector R-7 (and R-8?) now can tentatively be traced northward to the early Neogene (Grunau et al., 1975, fig. 6) volcanic aprons of the eastern Canary Islands. These volcanic aprons extend several tens of $\mathrm{km}$ seaward from the submarine volcanic cone of Gran Canaria and Fuerteventura into sediments of middle Miocene age, and are underlain by older sediments (see frontispiece; Figure 1, and Wissmann, this volume). Apparently, the volcaniclastic debris flows or turbidity currents have traveled for distances of 100 to 200 $\mathrm{km}$ down the island slopes and the South Canary Island Channel (Figure 1). They deposited their sediment load within the deepest part of that channel, where it is bordered by the foot of the Cape Bojador continental slope. Wissman (personal communication) has traced the extent of these volcaniclastic debris flows 


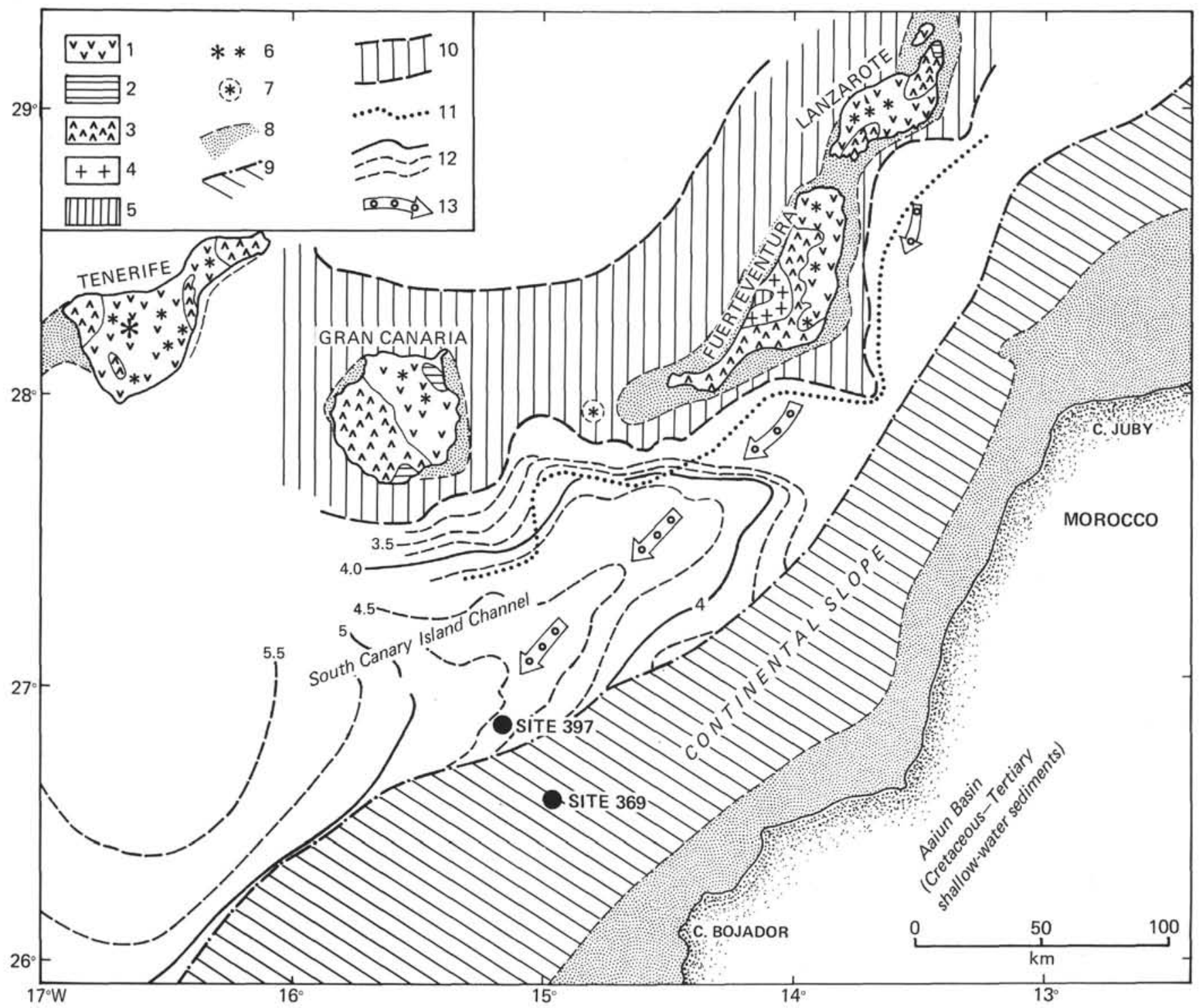

Figure 1. Location sketch of DSDP Site 397 with highly generalized geology of Tenerife, Gran Canaria, Fuerteventura, and Lanzarote after Fuster et al. (1968), Grunau et al. (1975), Schmincke (1976), and Mitchell-Thome (1976). Explanation of symbols: 1 = "young" ( $<5$ m.y.B.P.) volcanic rocks and pyroclastics (Plio-Pleistocene); $2=$ Miocene to lower Pliocene shallow-water sediments; $3=$ "old" (>9 m.y.B.P.) Miocene volcanic rocks and pyroclastics; $4=$ "basal complex" (upper Paleogene to lower mafic to ultramafic plutonic rocks, syenites, dike-in-dike complex, submarine volcanics etc of the Betancuria Massif); 5 = Cretaceous hemipelagic and terrigenous deep-sea sediments; $6=$ major Quaternary eruption centers; $7=$ young submarine volcano; $8=$ continental or island shelf with shelf break; $9=$ base-of-continental-slope boundary; 10 = "volcanic mass" or "socle", partly overlain by young sediments and/or pyroclastics; $11=$ seaward boundary of "volcanic apron," over-and underlain by sediments; 12 = middle Miocene paleobathymetry, indicated by depth contours of seismic reflector R-7 ("D2", see Figure 2) in seconds two-way travel time below sea level, to show submarine relief of South Canary Island Channel during deposition of volcaniclastic debris flows $V-1$ to $V-4 ; 13=$ inferred paleocurrent direction of volcaniclastic debris flows. Source for 7, 9-12: seismic reflection profiles interpreted by G. Wissmann (this volume).

by the correlation of reflection profiles. They can be mapped as a relatively narrow $(5-25 \mathrm{~km})$ tongue over a length of at least $220 \mathrm{~km}$ and an area of about $2000 \mathrm{~km}^{2}$ (see Site Chapter; Arthur et al., this volume). If we assume an average thickness of 20 to 30 meters for all volcaniclastic debris flows between reflectors R-7 and $\mathrm{R}-8$, we arrive at a total volume of 40 to $60 \mathrm{~km}^{3}$. This is less than 1 per cent of the volume of the Gran Canaria subaerial shield $\left(10,000 \mathrm{~km}^{3}\right)$ which was produced in less than 1 m.y. (MacDougall and Schmincke, 1977). The 


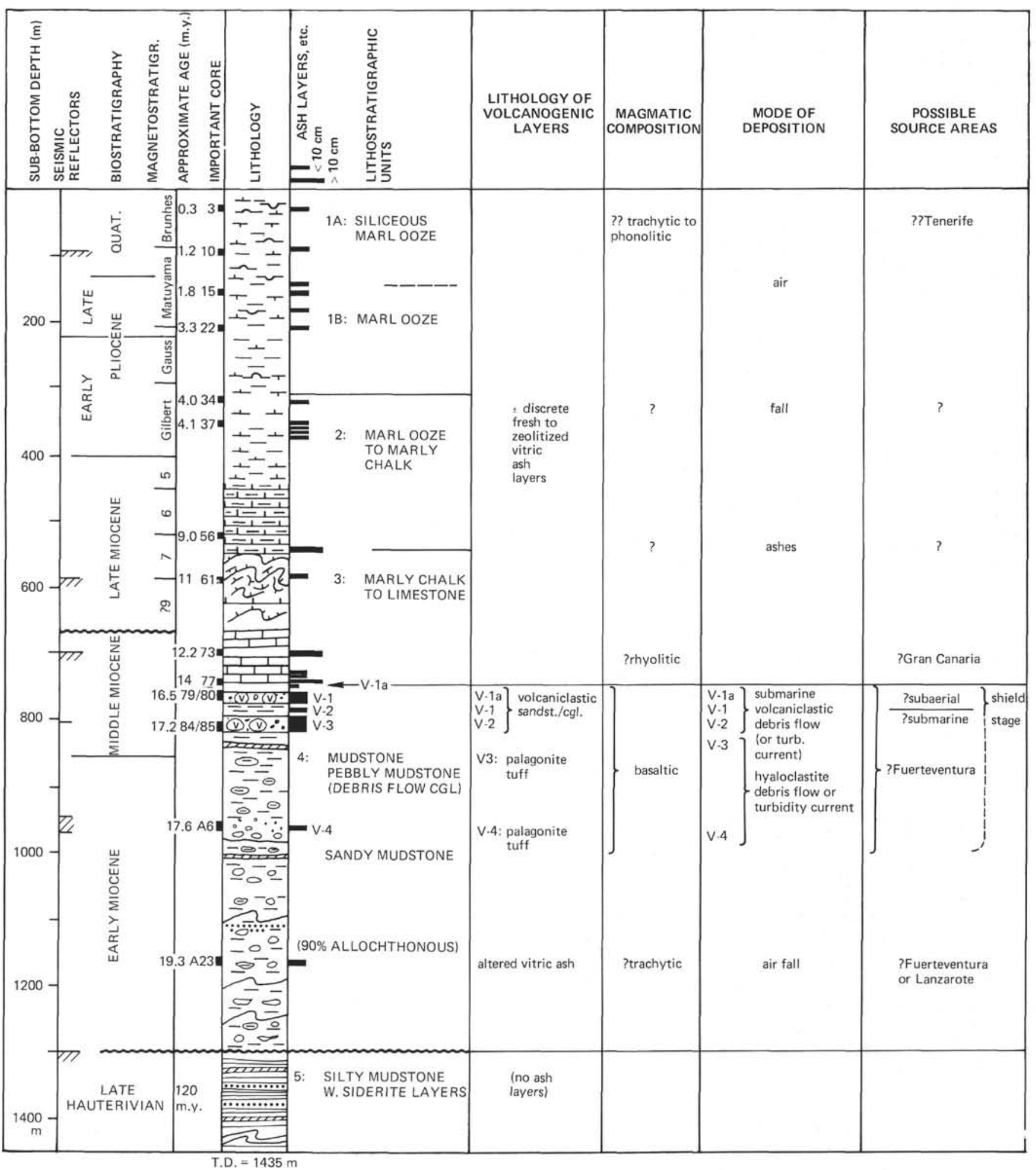

Figure 2. Generalized lithostratigraphic diagram of DSDP Site 397 (Holes 397 and 397A) with acousto-, bio-, and magnetostratigraphy, approximate age, location, and lithology of volcaniclastic layers. The genetic interpretation (magmatic composition, mode of deposition, and possible source areas) is tentative and discussed in the text. Besides airfall ashes, there are current transported volcaniclastic (tuffaceous) sandstones containing volcanic and nonvolcanic components (V-1a to V-4). 
significance of the age of the different volcanic events, the mode of deposition, and possible source areas (Figure 2) are discussed later in this report.

No volcanogenic sediments were found in the Lower Cretaceous lithostratigrapic Unit 5.

\section{ASH LAYERS}

About 15 ash layers have been recognized so far in the entire section, ranging in age from 19.3 to 0.3 m.y. B.P. (Table 1). Their maximum thickness is 20 to 25 cm (Sections 397-73-1 and 397-77-2), but most layers are less than $5 \mathrm{~cm}$, and some less than $1 \mathrm{~cm}$ thick. The median grain size of all ashes is less than $1 \mathrm{~mm}$ and most are between 0.05 and $0.15 \mathrm{~mm}$. The significant differences among the ash layers as to type of shard, degree of alteration, and proportion of non-volcanic constituents are discussed below (see Table 1).

\section{Felsic Glass Shards}

Two major types of shards of felsic composition were found in the ash layers: composite (pumice) shards and simple (tricuspate and bladed) shards (Plate 5, Figure 1). Both types occur in all ash layers; pumice shards are generally more common in the larger grain size (medium to coarse ash size). Nevertheless, the ash layer of Sample 397-22-7, CC is dominated by pumice shards. Very small pumice shards $(<0.1 \mathrm{~mm})$ also are the dominant type of shard in Core 397-77. In younger ashes (Cores 397-10, 397-14, and 397-15), tricuspate shards are most common, and pumice is also more fibrous (tubular vesicles) than in the older ashes. The reason for these differences is unknown.

Color of the shards varies from white or very light gray to brown (most common) to dark brown (particularly some thicker-walled tricuspate shards in Cores 397-77 and 397-22). Shards of several colors occur in some ash layers (particularly in Cores 397-77 and 397 22 ) while, in the younger ashes, shard color is more uniform in a given sample. These color differences are probably due to differences in both vesicularity and chemical composition.

Refractive index shows that shards from the upper layers $(n \sim 1.535)$ are less silica rich (phonolitic?) than those of some glass shards from the older ash layers ( $n$ 1.52 rhyolitic?).

Shards in most younger ash layers are relatively fresh, although probably hydrated and chemically changed to some degree. However, many shards are replaced by zeolites (mainly phillipsite; Sample 397 $61-4,109 \mathrm{~cm}$ contains apparently clinoptilolite) in ash layers (see Reich, this volume) and the oldest trachytic (?) airfall ash (Sample 397A-23-3, 30-33 cm) is almost completely altered to montmorillonite (Plate 5, Figure 1).

\section{Non-Vitric Components}

Most ash layers contain some less-vesiculated volcanic components, some pyrogenic crystals, and varia- ble amounts of non-volcanic components. Pyrogenic crystals are dominantly alkali feldspar, with minor amphibole and $\mathrm{Fe} / \mathrm{Ti}$-oxide. Non-volcanic constituents are chiefly quartz and biogenic debris. Pumice shards have lower settling velocities than tricuspate shards; therefore, ash layers dominated by pumice shards have a greater chance to be diluted by non-volcanic components.

\section{PETROGRAPHY OF VOLCANICLASTIC SANDSTONE}

\section{Texture and Nomenclature}

Nearly all volcaniclastic rocks have median diameters in the sand-size range (Table 1). Most of the clasts, which are often oriented parallel to the bedding, are in less than three Wentworth size grades and form relatively well-sorted assemblages. They are always embedded in a fine-grained matrix (see below). Some of the clasts are flattened (?deformed during or after deposition, F. McCoy, personal communication).

The tuffaceous sandstone layer "V-1" (Cores 39779 and 397-50) is a 4.3-meter-thick, massive, extremely poorly to moderately sorted debris flow deposit (Table 1, Plate 1). The top of the flow (Section 397-79-2) is a fine to medium sandstone (Plate 2, Figure 1) grading downward into a pebbly coarse sandstone to sandy conglomerate (Plate 2, Figure 2). The diameters of rounded quartz and angular pyroxene grains range from 0.05 to $2.0 \mathrm{~mm}$ and those from volcanic rock fragments generally range from 1 to $5 \mathrm{~mm}$ (up to 2 $\mathrm{cm})$. The maximum clast sizes $(>5 \mathrm{~cm})$ occur not at the base, but near the middle part of the flow (Plate 2, Figure 3 ). The basal third of the flow is suprisingly homogeneous and less coarse-grained, and only the lowermost $10 \mathrm{~cm}$ is distinctly graded (Plate 2, Figure 4).

The massive unit "V-3" (Cores 397-84 and 397-85) is a 7.8-meter-thick hyaloclastic turbidite with a strikingly different texture (Table 1). It is much finer grained (sandstone, no pebbles $>_{2} \mathrm{~mm}$ ) and much better sorted than V-1 (Plate 3, Figure 4).

Consolidated ashes (mainly 0.063 to $2 \mathrm{~mm}$ ) are called "tuffs," and consolidated lapilli $(>2 \mathrm{~mm})$ are called "lapillistones" (Schmincke, 1974). Because the volcanic fragments in the volcaniclastic debris flows (e.g., V-1) are generally "epiclastic," i.e., fragmented by erosion and not by pyroclastic and hydroclastic processes, they may be called tuffaceous (or volcaniclastic) sandstones. Such redeposited volcaniclastic rocks generally contain various amounts of non-volcanic components.

Some of the "hyaoloclastites" of flow V-3 are vitric tuffs, containing mainly volcanic debris (altered glass) of hydroclastic and pyroclastic origin.

A mixed epiclastic-volcaniclastic sandstone ("hyaloclastite V-4") was discovered at 960 to 990 meters (397A-6-7, early Miocene). This poorly sorted sandstone is about 20 to $30(?)$ meters thick and contains 30 per cent quartz and 25 per cent altered palagonite in a 
TABLE 1

Station Data, Texture, and Petrography of Investigated Volcanic Ashes and Volcaniclastic Sediments

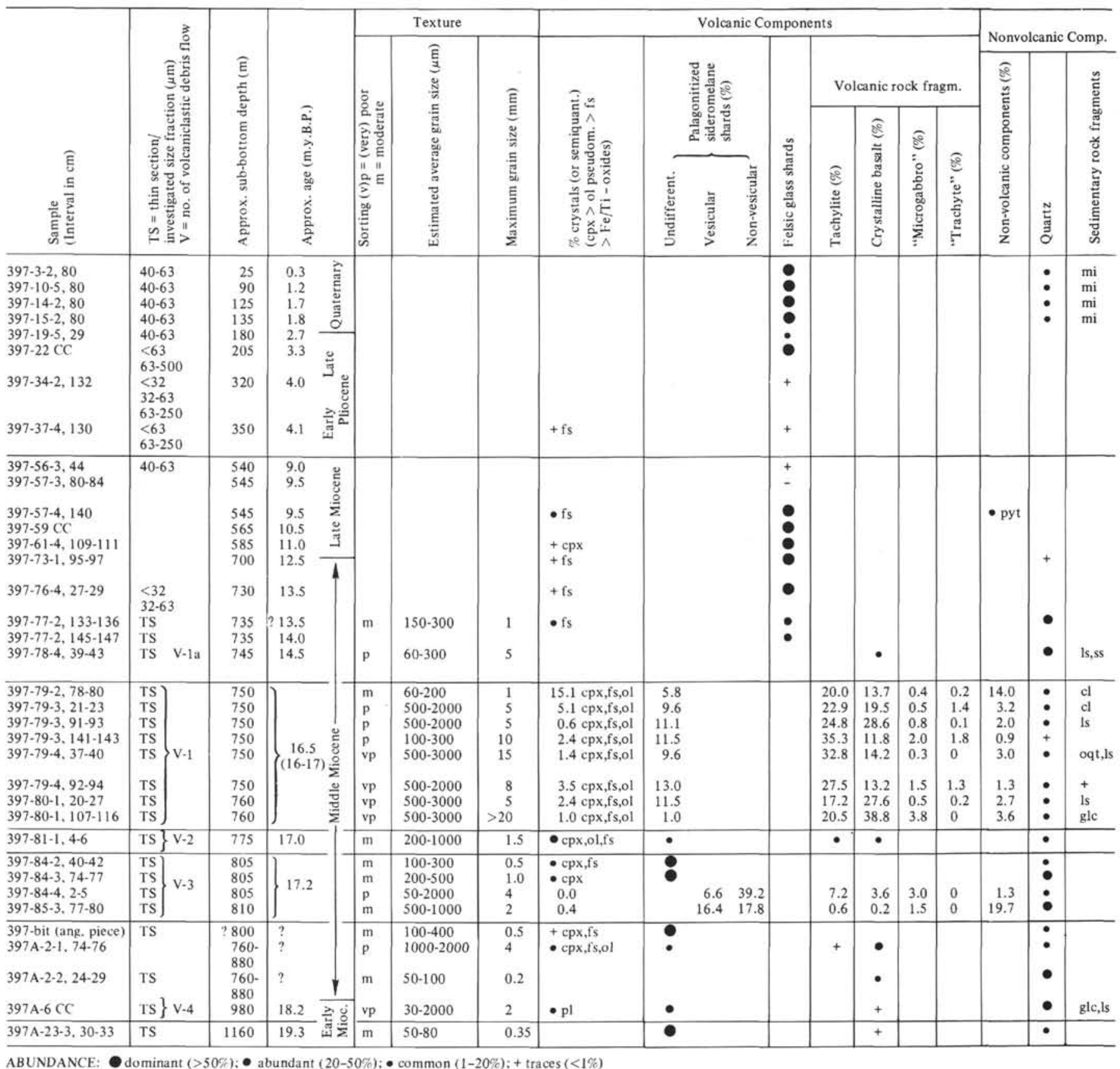

Note: Modal composition (point count analysis) only examined from ten volcaniclastic sandstone and hyaloclastite samples (see Figure 3). All other petrographic data are semiquantitative estimates from thin-section, smear slide, coarse-fraction, or X-ray diffraction (H. Rösch) analysis. "Crystals" and "fossils" listed in order of decreasing abundance. Abbreviations: Minerals: an $=$ analcime, a.m. $=$ X-ray amorphous matter, amph $=$ amphibole, ca $=$ calcite, $\mathrm{cpt}=$ clinoptilolite, $\mathrm{cpx}=$ clinopyroxene, $\mathrm{do}=$ dolomite, $\mathrm{fs}=$ feldspar, glc $=$ glauconite, go $=$ goethite, $\mathrm{ka}=\mathrm{kaolinite}, \mathrm{mi}=\mathrm{mica}, \mathrm{mtm}=\mathrm{montmorillonite}$, $\mathrm{ol}=$ olivine, $\mathrm{opCT}=$ opal-CT, $\mathrm{ph}=$ phillipsite, $\mathrm{pl}=$ plagioclase, $\mathrm{pyt}=$ pyrite, $\mathrm{q}=$ quartz, sim $=$ sideromelane, Rock fragments: $\mathrm{cl}=$ claystone, $\mathrm{gl}=\mathrm{glass}$, Is $=$ limestone, ot $/ \mathrm{mt}=$ ortho/metaquartzite, $\mathrm{pal}=$ palagonite, $\mathrm{ss}=$ sandstone. Fossils: by $=$ bryozoans, $\mathrm{fm}=$ foraminifer, ech $=\mathrm{echinoid}, \mathrm{li}=\mathrm{calcareous}$ algae (e.g. Lithothamnium), mo = mollusk, $\mathrm{np}=$ nannoplankton $($ coccoliths, etc.), pe = pelecypod, sil $=$ siliceous organisms. 
TABLE 1 - Continued

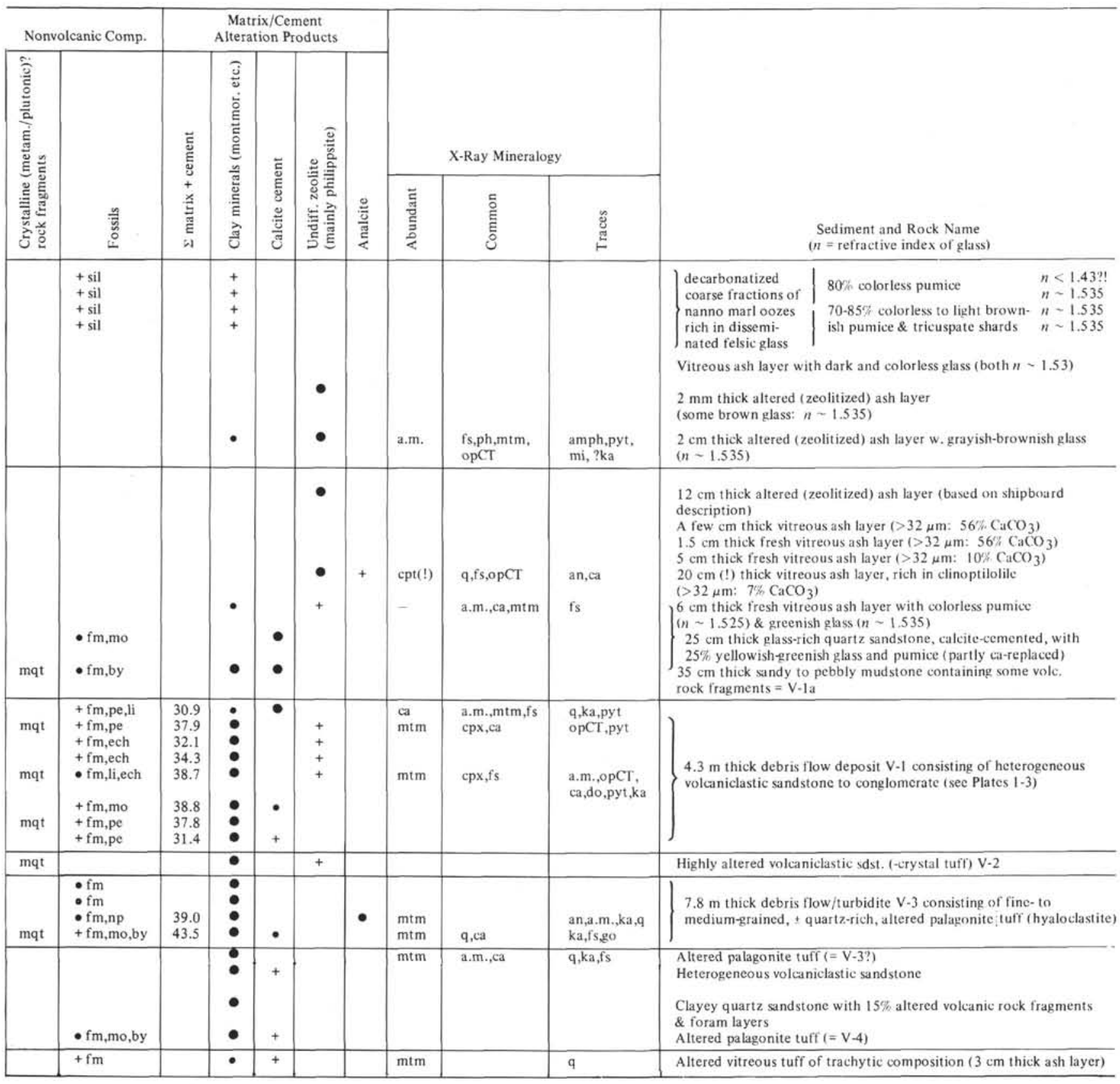


clayey matrix (see Arthur and von Rad, this volume). It is probably the cause for the impedance change, producing reflector R-9 ("rise- ${ }_{1}$ "; see Site Chapter).

\section{Igneous Components}

\section{Minerals}

\section{Clinopyroxene}

Clinopyroxene is ubiquitous in all volcaniclastic rocks (Plate 3, Figures 1 and 3; Plate 4, Figures 1 and 3 ). It occurs as single crystals and as pheoncrysts in rock particles, generally in amounts less than 1 per cent by volume. Clinopyroxene is up to $2 \mathrm{~mm}$ long and probably of titanaugite composition, judging from its color and common twinning and zoning (Plate 4, Figure 2). Titanaugite is by far the freshest of all pyrogenic minerals, although in many rocks it is partially altered. Replacement minerals are carbonate and, less commonly, layered silicate (smectite?). Titanaugite is also common as a groundmass phase in the more coarsely crystallized rock fragments, most of which are quite fresh (Plate 4, Figure 1).

\section{Olivine}

Olivine occurs as carbonate and, less commonly, layered silicate (smectite?) pseudomorphs (Plate 5, Figure 2 ) in all volcaniclastic sandstones, both as single crystals and as phenocrysts in rock particles. Because it is always completely replaced, exact estimates of its volume percentage are impossible; it may be slightly more abundant than clinopyroxene. In some microgabbros (Plate 3, Figure 1), olivine is replaced by serpentine, apparently a pre-depositional alteration that is stable in the present environment. Moreover, much of the olivine occurring as phenocrysts in rock fragments had been previously altered to iddingsite along their margins, probably during cooling and subaerial weathering.

\section{Feldspar}

Plagioclase is the most abundant feldspar phase. It occurs both as phenocrysts (Plate 4, Figure 2) and groundmass crystals (Plate 4, Figures 1 through 4) but, in contrast to pyroxene and olivine, rarely as single crystals. This indicates that liquidus phases in the basalts, the dominating rock type, were chiefly olivine and olivine plus clinopyroxene.

Plagioclase is generally albitized and partly replaced by smectite(?), chlorite(?), or carbonate. Fresh plagioclase occurs in a few rock fragments, especially in nonvesicular tachylite.

Feldspar microlites in more felsic rocks, especially trachyte, are probably anorthoclase and perhaps sanidine in some rocks (Plate 4, Figure 4). K-feldspar also occurs in the groundmass of some well-crystallized alkalic microgabbros.

\section{$\mathrm{Fe} / \mathrm{Ti}$ Oxides}

Titanomagnetite (?) is a ubiquitous groundmass phase in all basaltic rock fragments except sideromel- ane shards (Plate 4, Figure 1). As a phenocryst phase, it occurs only in the more differentiated rock (Plate 5, Figure 2).

Titanomagnetite(?) is a ubiquitous groundmass phase in all basaltic rock fragments except sideromelane shards (Plate 4, Figure 1). As a phenocryst phase, it occurs only in the more differentiated rock (Plate 5, Figure 2).

Other phases include minor amounts of amphibole, mica, and apatite (Table 1).

\section{Igneous Rock Fragments}

\section{Alkalic Microgabbros}

The term "microgabbro" is used loosely here for rocks which (a) are holocrystalline; (b) are relatively coarse-grained, though mineral components are generally less than $2 \mathrm{~mm}$ in diameter; (c) have an isotropic fabric such as subophitic intergrowth suggesting growth during near-static conditions; and (d) in some cases, have a decidedly alkalic composition as indicated by biotite or amphibole (Plate 3, Figure 1d). Fragments of these "microgabbros" can be derived from the center of lava flows several meters thick; more likely, they originated from subvolcanic intrusive bodies, because thick flows are not common among the shield-building lavas in the Canary Island. Several thin-sections contain one or more such fragments, although their total volume is less than 5 volume per cent of all volcanic rocks (Table 1).

\section{Crystalline Basalt}

We use the term "crystalline basalt" here for rocks which are (a) holocrystalline; (b) fine-to-medium grained; and (c) commonly have a slightly flow-aligned fabric (c in Plate 3, Figures 1 through 3). Mineralogically, apart from phenocrysts, they consist predominantly of plagioclase and clinopyroxene microlites, with minor titanomagnetite (Plate 4, Figure 1). There are all gradations from microgabbros to fully crystallized basalts. Basalts, as used here, encompass the more mafic varieties such as ankaramites and picrites, and the more evolved types, hawaiites and mugearites (Plate 4, Figure 3).

\section{Tachylite}

When basaltic and intermediate lava is rapidly cooled (not quenched), it forms an oxide-studded opaque rock called "tachylite" which sometimes contains microlites and phenocrysts. We distinguish two varieties of tachylite in the rocks studied: type 1 is vesicular and appears to have formed as a primary pyroclastic particle judging from its shape $\left(\mathrm{b}_{1}\right.$ in Plate 3 , Figures 2 and 3; Plate 4, Figure 6). Type 2 is generally less vesicular and angular, and may have formed by breakage during erosion or granulation by contact with seawater $\left(b_{2}\right.$ in Plate 3, Figures 2 and 3; Plate 4, Figure 5). In general, tachylite fragments are larger in size than associated fragments of the rock types discussed above. This may be controlled to a minor degree by 
density differences causing larger particles of the less dense and more vesicular tachylite to be hydraulically equivalent to smaller fragments of the denser crystalline basalt; it may, however, also be due to shorter transport distances. While the microgabbros may break up more easily during erosion than the "tougher" basalt, they also may have come from a more distant source. The presence of vesicular tachylite, and tachylite showing little evidence of rounding (in contrast to all crystalline basalt and microgabbro fragments), suggests strongly that some or most of the tachylite was generated not far from shore, perhaps in the littoral zone.

There are all gradations between tachylite and crystalline basalt, and transitional varieties are more abundant than between crystalline basalt and microgabbro or between tachylite and sideromelane (Plate 3 ).

\section{Rock Fragments of Intermediate and Felsic Composition}

Some rock fragments have only small amounts of mafics and oxides and a few consist almost exclusively of feldspar microlites; both rock types commonly have a pronounced trachytic texture. We interpret these rocks as "trachyandesite" ("intermediate" benmoreite) and "trachyte," respectively (Plate 4, Figure 4). The volume of these rocks is always less than 5 and generally less than 1 per cent by volume, although in the tachylitic and glassy components exact estimates of chemical composition cannot be made. No highly differentiated rocks that could be called phonolite or rhyolite were found.

\section{Sideromelane Shards}

We use the term sideromelane for formerly glassy shards which are now completely changed into palagonite, as in the hyaloclastites (Plate 4, Figures 5 and 6), or layered silicates (Plate 5, Figure 3 ), and rarely carbonate as in the volcaniclastic sandstones. Among some 15,000 points counted, only 2 glass fragments were found that were completely isotropic. They probably consist of hydrated and chemically changed glass. From the shape of the shards, a generally low degree of vesiculation, and their association with more crystalline varieties, we assume that they once were sideromelane, i.e., transparent glass of basaltic composition. We distinguish two varieties: non-vesicular angular shards with no or rare vesicles, as dominating in hyaloclastite (e.g., Sample 397-84-4, 2-5 cm), or more vesicular varieties which might be termed "scoria" (e.g., Sample 397-85-3, 77-80 cm). The rare glass fragments in the volcaniclastic sandstones (Table 1; Plate 4, Figure 6; Plate 5, Figure 3) are extremely vesicular (round vesicles) and might be called "pumice" (of basaltic composition).

\section{Modal Composition}

Modal compositions were determined in 10 thin-sections by counting from 1100 to 2300 points in each section (Table 1; Figure 3). Compositions are only approx- imate for some components, however, because there are many difficulties in making exact identifications of some types of clasts. For example, glass is probably under-represented in the counts, because it is always completely replaced, mostly by brown clay or rarely by carbonate. Likewise, olivine is always completely replaced and clinopyroxene and plagioclase are partly pseudomorphed by phyllosilicates and/or carbonate. For these reasons, matrix (and cement) are maximum values and their volume contains probably about 10 to 15 per cent of the replaced components listed above. Minerals, chiefly clinopyroxene, are only counted as separate components when they occur as single crystals. When they occur as phenocrystic or groundmass phase in rock fragments they are counted with the specific type of rock fragment.

Three main rock types can be distinguished from modal compositions; most thin-sections are from the massive volcaniclastic debris flow V-1 (Cores 397-79 and 397-80, Figure 2). Within this unit, significant variations exist (Table 1), most of which are shown graphically in Figure 3 and in the photomicrographs of Plates 3 and 4. Shards, mostly highly vesicular, occur throughout the unit in fairly equal amounts except in the basal specimen where they are practically absent. Crystals are abundant in the fine-to-medium grained sandstone from the top of debris flow V-1, where they make up 15 modal per cent. In most other specimens, however, they comprise less than 3 per cent and are rare in the basal part of debris flow V-1. Tachylite, crystalline basalt, and microgabbro are fairly evenly distributed throughout most of the unit, except near the base where crystalline basalt and microgabbro are strongly concentrated relative to tachylite (Figure 3a). Non-volcanic fragments are slightly enriched in the basal layer of V-1 and are abundant at the top (Figure 3d). Most of these changes in modal composition are clearly controlled by textural variations which, in turn, are related to the position within the debris flow. The coarse-grained base (median $>2 \mathrm{~mm}$ ) contains relatively abundant dense rock fragments, while single crystals and detrital non-volcanic mineral grains occur in the smaller size grades and therefore, are, enriched in the fine-grained top of the unit. This distribution is consistent with the depositional model suggested by the shipboard party (mass flows encompassing distal debris or grain flows and/or turbidity currents) and which is discussed in more detail by Arthur and von Rad (this volume).

The second main class of rocks differs from the above chiefly in the much higher content of palagonitized sideromelane shards (Table 1; Figure 3); since those shards are generally dense to moderately vesicular (Plate 4, Figure 5), we call these rocks hyaloclastites. The hyaloclastites occur mainly in the more finegrained, massive debris flows or turbidites V-3 and V-4 (Cores 397-84 and 397-85; Sample 397A-6-3, CC; Figure 2 ), show significant variations. Single crystals are particularly rare in both hyaloclastites (Figure $3 \mathrm{c}$ ), while microgabbros are relatively abundant (Figure $3 b$ ). Non- 


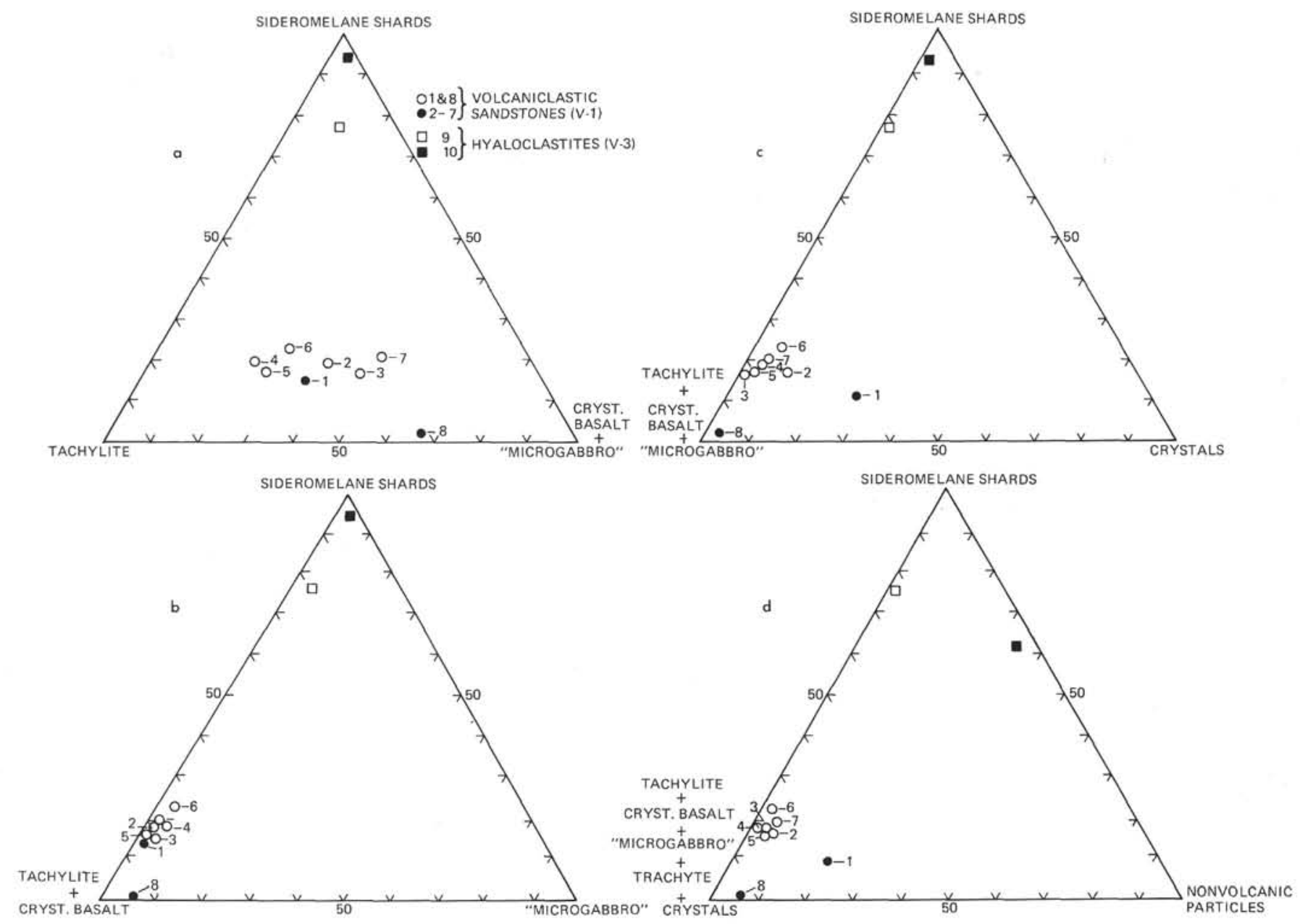

Figure 3. Petrography (modal composition from point count analysis) of volcaniclastic sandstones (samples 1 through 8 ; $V$-1) and palagonite tuffs (altered hyaloclastites, samples 9 and $10 ; \mathrm{V}-3$ ). Sample numbers (see Table 1): 1 = 397-79-2, 78-80 cm; $2=397-79-3,21-23 \mathrm{~cm} ; 3=397-79-3,91-93 \mathrm{~cm} ; 4=397-79-3,141-143 \mathrm{~cm} ; 5=397-79-4,37-40 \mathrm{~cm} ; 6=397-79-4,92-94$ $\mathrm{cm} ; 7=397-80-1,20-27 \mathrm{~cm} ; 8=397-80-1,107-116 \mathrm{~cm} ; 9=397-84-4,2-5 \mathrm{~cm} ; 10=397-85-3,77-80 \mathrm{~cm}$.

volcanic components are rare in Core 397-84 but are unusually common (sandstone fragments) in Core 397 85 (Plate 3, Figure 4) which also contains much more vesicular shards than Core 397-84.

A third class of rocks, not studied in detail, contains a few scattered volcanic rock fragments in the "muddy" matrix of a marly conglomeratic sandstone (e.g., Sample $397-78-4,39-43 \mathrm{~cm}=\mathrm{V}-1 \mathrm{a})$. A clayey very fine quartz sandstone alternating with layers of foraminiferal sand (?contourite) contains about 15 per cent of altered volcanic rock and glass fragments (Sample 397A$2-2,24-29 \mathrm{~cm})$.

\section{Non-Volcanic Components}

There are two main types of non-volcanic components. The most common is single grains of quartz, feldspar, and rock fragments such as quartzite. Possibly, the high quartz and quartzite content indicates derivation from Cretaceous quartz sandstones on Fuerteventura rather than from the African mainland (see below).
The other type of clast is made of various types of biogenic debris. These are often replaced and recrystallized so their volumetric abundance is underestimated.

\section{Quartz}

Epiclastic quartz grains are quite common in the volcaniclastic sandstones of debris flows V-1 (Plate 3, Figure 3 ) and V-3 (20 to $30 \%$ in Samples 397-85-3, 77 $\mathrm{cm}$ and 397A-6-3, CC; see Plate 3, Figure 4). Small silt-sized grains are angular, whereas the larger grains are well-rounded and commonly polygranular, grading into quartzite.

\section{Sedimentary Rock Fragments}

Sedimentary rock fragments are common in debris flow V-1 and include quartzose limestone (Sample 397-79-3, $91 \mathrm{~cm}$ ), foraminiferal micrite (Sample 397A$1,74 \mathrm{~cm}$ ), marlstone (Plate 2, Figure 3), and silicified(?) claystone fragments which are sometimes difficult to distinguish from altered fine-grained volcanic rocks (Table 1). Glauconite, and oncoids, which are 
slightly broken, healed by secondary calcite, and overgrown by calcareous algae and bryozoans, testify to a shallow-water photic zone source environment of those components (Plate 5, Figure 7). Those sedimentary rock fragments and fossils were either derived from the littoral zone, or picked up by the volcanic debris flow on its way to the South Canary Island Channel.

\section{Crystalline Rock Fragments}

Crystalline rock fragments occur only in debris flows V-1 and V-1a and include polycrystalline quartz grains with feldspar and amphibole (up to $5 \mathrm{~mm}$ ) and "metaquartzite" with elongated quartz grains and crenulated crystal boundaries (Plate 5, Figure 6). The ultimate source of those grains is enigmatic: most of the polycrystalline quartz is probably of plutonic origin, whereas the metamorphic rock fragments might be derived from the Cretaceous terrigenous sediments underlying the Betancuria Massif of Fuerteventura (Rothe, 1968; Schmincke, 1976). According to Bernoulli et al. (in press), the Lower Cretaceous flysch-type sediments were deposited in a distal deep-sea fan or rise environment extending off northwest Africa prior to the early Neogene volcanic uplift of the Canary Archipelago.

\section{Fossils}

Planktonic foraminifers are common (e.g., Plate 4, Figure 5; Sample 397-80-1, $29 \mathrm{~cm}$ ), benthic foraminifers rare (Samples 397-85-3, $77 \mathrm{~cm}$ and 397A-79-2, 78 $\mathrm{cm}$ ). Bryozoans (Samples 397-78-4, $39 \mathrm{~cm}$, and 397 $85-3,77 \mathrm{~cm}$ ), echinoid fragments, and calcareous algae ("Lithothamnium"; Plate 5, Figure 8) indicate a shallow-water source environment for these components, possibly an island shelf.

\section{Alteration and Secondary Minerals (matrix/cement)}

The main components of the volcanic rock particles are glass, and the mineral phases clinopyroxene, olivine, and plagioclase. Of these, glass and olivine are always completely altered, mostly to phyllosilicates (probably smectite) and carbonate. In general, carbonate (mostly calcite), which partly or completely replaces phyllosilicates, is a later diagenetic phase. We are unable to determine why clinopyroxene and plagioclase are remarkably stable, although the feldspar is more easily altered than clinopyroxene. Such differences are typical of moderately altered sequences of basaltic submarine series (see, e.g., La Palma pillow complex: Schmincke and Staudigel, 1976). Alteration was apparently dominated by pore solution chemistry and not be elevated temperatures, as this would have led to complete albitization of the plagioclase and formation of quartz, epidote, and other phases (Schmincke and Staudigel, 1976). Measured in-situ temperatures of about $40^{\circ} \mathrm{C}$ at 750 to 800 meters (see Site Report, this volume) suggest that alteration may be more advanced than in rocks of similar age in low heat-flow areas.

There are three main types of secondary minerals: "layered silicates" (clayey matrix) carbonate, and zeolites.

\section{Clayey to Marly Matrix}

By far the most common secondary minerals in both rock types are "layered silicates" which occur in several varieties, distinguished by color, birefringence, and habit. Most common are light brown "smectites" and some illite(?) which make up much of the "matrix" and are also found as pseudomorphs of olivine, glass, etc. They generally occur as vermicular aggregates. At the other end of a wide color spectrum are deep green to blue-green varieities which are not common and occur mainly in vesicles of sideromelane shards (Plate 5, Figures 3 and 4 ). They encompass glauconite-celadonite and perhaps some chlorite. Serpentine was found only as rare pseudomorphs of olivine, chiefly in the microgabbros; very likely it formed prior to erosion and sedimentation.

The matrix of the volcaniclastic debris flow V-1 (e.g., Sample 397-79-4, $92 \mathrm{~cm}$ ) consists of yellowish green, isotropic to cryptocrystalline clay minerals (Plate 3 , Figure 3 ). This phyllosilicate might be a diagenetically altered smectite (montmorillonite, XRD determination by $\mathrm{H}$. Rösch) of volcanogenic origin, although this problem should be further investigated (see also Riech, this volume; Chamley and d'Argoud, this volume). The hemipelagic foraminiferal marlstone underlying flow V-1 (Sample 397-80-1, $107 \mathrm{~cm}$ ) is distinctly different from the brownish cryptocrystalline, clayey (?smectite) matrix (Plate 2, Figure 4). This also suggests that a large part of the green clay matrix is derived from fine-grained altered ash material.

The clayey to marly matrix (e.g., in debris flow V-3; Sample $(397-84-4,2 \mathrm{~cm})$ contains some foraminifers, coccoliths, and discoasters (Plate 4, Figure 5). In this case, the clay fraction might be identical to, or mixed with the underlying hemipelagic marl.

\section{Carbonate Cement}

Carbonate occurs in all rocks, although mostly in small amounts ( $<10 \%$ of the secondary minerals), while it is the chief secondary mineral in Sample $397-$ $79-2,78$ to $80 \mathrm{~cm}$ and common in Sample 397-79-4, 92 to $94 \mathrm{~cm}$. It ranges in form from small euhedral crystals embedded in a clay matrix (Sample 397-85-3, 77$80 \mathrm{~cm}$ ) to sparry cement and large poikiloblastic crystals replacing rock fragments or minerals (especially Sample 397-80-1, 107-116 cm). Carbonate is generally the latest in the paragenesis of secondary minerals. According to a few XRD analyses, ferroan (ca.1\% Fe) calcite appears to be the most common carbonate $(\mathrm{H}$. Rösch, personal communication).

Secondary calcite cement (sometimes as microcrystalline A-cement and drusy B-cement as last generation filling) occurs especially in debris flow V-1 (Table 1). In some rocks, calcite fills small veinlets in the clayey matrix. In debris flow V-3, 5 per cent of recrystallized micro- to macrosparitic cement is present.

\section{Secondary Zeolite Cement}

The least common secondary phases are zeolites (see also Riech, this volume). They occur in all investigated 
specimens, although usually in small amounts. Large amounts of fibroradiated to bladed zeolite crystals (20$30 \mu \mathrm{m}$ long), probably phillipsite, are the latest cement and fill open cavities in the volcaniclastic sandstones of flow V-1 (e.g., Samples 397-79-3, $31 \mathrm{~cm}$; and 397-79-3, $91 \mathrm{~cm}$; Plate 5, Figure 5). In the hyaloclastite of flow V-3, zeolites make up a few per cent. In one specimen, a macrocrystalline zeolite cement was determined by XRD as analcime (H. Rösch; Table 1). Smaller amounts of phillipsite and rare chabazite(?), not detected by XRD might be present. In several rocks, textural evidence suggests that zeolites formed from layered silicates, while in most volcaniclastic sandstones zeolite forms rims around cavities, but is later replaced by carbonate.

Other phases of diagenetic origin include pyrite and Ti-phases (possibly anatase or leucoxene) which occur in concentric bands inside palagonitized sideromelane shards (Plate 5, Figure 2).

\section{DISCUSSION}

\section{Origin and Deposition of Clastic Volcanic Debris}

Three processes may lead to the deposition of clastic volcanic debris on the sea floor: (1) eruption and production in situ; (2) transportation of volcanic debris erupted at the sea floor from a distant location (midocean ridge, fracture zone, seamount) to the present site of deposition by currents; and (3) eruption on land with (a) direct fallout and sedimentation in the sea or (b) erosion, subsequent reworking, and downslope transport onto the sea floor.

There is no evidence for model 1 , as the volcanic components are always interbedded or intermixed with non-volcanic detritus. In support of model 2, submarine volcanoes or the submarine stage of a volcanic island are likely sources for the hyaloclastites. Most of the volcanic material, however, is probably related to the nearby Canary Islands, i.e., model 3-a can be applied for the ashes and model 3-b for the "debris flows."

Before we concentrate on a specific island, we may subdivide the rock types into different groups according to their possible occurrence during various evolutionary stages of an oceanic island.

There are four major clastic processes by which volcanic material from a seamount or volcanic island is generated and can be supplied to bottom sediments:

a) Shard and pillow formation during the submarine stage. We tentatively interpret the samples taken from the drill bit of Hole 397 as representing a relatively deep water stage (because of the non-vesiculated nature of most shards); and Samples 397-84-4, 2-5 cm and $397-85-3,77-80 \mathrm{~cm}$ from debris flow V-3 as representing a shallow-water stage (more vesicular shards) in the construction of a seamount. The latter two samples probably indicate partial emergence of an island containing alkalic gabbroic rocks.

b) Fragmentation of lava flows entering the sea from land. This process produces large volumes of tachylitic to finely crystalline rock fragments. c) Erosion of volcanic and plutonic rocks deposited and cooled on land and transported into the sea by rivers. The evidence that these components are derived from a volcanic island is manyfold. Alkalic composition as described above is typical of volcanic rocks from islands in general and the Canary Islands in particular. Shield-building basalts are usually by far the most voluminuous rock types on the Canary Islands. They closely resemble the crystalline basalt fragments in the volcaniclastic sandstones (V-1), with olivine and titanaugite as main liquidus phases, and clinopyroxene and plagioclase dominating the groundmass mineralogy. Iddingsitization and, in a féw specimens, former high-temperature oxidation of olivine crystals are further evidence that these rocks crystallized in a subaerial environment. Finally, the great variety of rock types ranging from alkalic microgabbros through basalts to trachytes is generally not developed in a submarine volcanic rock association, but is fairly typical of oceanic islands, especially the Canaries (see review of the geology of the Canary Islands by Schmincke, 1976).

d) A fourth process would be highly explosive eruptions, principally of more differentiated magma on an island. This process, responsible for the ash layers, involved vertical projection in high eruption columns, lateral eolian transport, and sedimentation by passive fallout through the water column.

\section{Source Area of Volcaniclastic Debris Flows}

Based on our conclusion that the Canary Islands are the most likely source area for most or all of the volcanic components found in Holes 397 and 397A, we next may ask which of the islands is the most likely source area, if individual islands can be singled out. Judging from the proximity to the drilling site, Gran Canaria would have been the most likely candidate, as originally proposed by the shipboard party. However, detailed data on the geochronology, geology, petrography, and chemistry of the early subaerial history of Gran Canaria (Schmincke, 1976; MacDougall and Schmincke, 1977; Lietz and Schmincke, 1975) indicate the following: (a) the island did not rise above sea level prior to about 14 m.y.B.P., (b) there are no known Miocene alkali gabbros, and (c) the differentiated lavas and ignimbrites overlying the shield basalts are dominantly rhyolites and later nepheline phonolites. On the other hand, the reported ages of shield basalts of the island of Fuerteventura (Figure 2) span the range from 11 to 20 m.y.B.P. (see Arthur et al., this volume). This age range would fit well with the age of Cores $397-78$ to $397-85$ (17 to 15.5 m.y.B.P.). If these debris flows directly reflect the major phase of shield building, this would strengthen the conclusion of Schmincke (1976) and MacDougall and Schmincke (1977) that shield-building stages on the Canary Islands are very short-term events (subaerial shield phase on Gran Canaria: 13.7 to 13.5 m.y.B.P.) and that some of the previously published age determinations are in error. Nevertheless, there are also older plutonics, ranging from ultramafics to syenites, exposed on Fuerteventura as well as trachytes older than the 
Miocene shield basalts (Fuster et al., 1968). Ages for these older rocks range from middle Miocene to Oligocene (maximum age: 38.6 m.y.B.P.; AbdelMonem et al., 1971), 20 m.y. old. Grunau et al. (1975) suggest that the bulk of plutonic and dike-in-dike rocks are not much older than early Miocene. Thus, the age and (to a lesser degree) composition of volcanic components indicate that Fuerteventura may have been the main source area for the volcanic sandstones encountered at Site 397 (Cores 397-78 to 397-85).

\section{CONCLUSIONS: RECONSTRUCTION OF THE EARLY EVOLUTION OF THE CANARY ISLANDS}

1. Starting with the oldest investigated pyroclastic sample, there was apparently a large trachytic explosive eruption about 19 m.y. ago (early Miocene) which produced glass shards, pumice, rock fragments, and feldspar crystals, all of trachytic composition (Figure 2). The source is unknown, but could have been Fuerteventura or Lanzarote judging from age data of similar rock types on these islands (Abdel-Monem et al., 1971).

2. The next younger rocks (about 17 to 17.6 m.y. B.P., lowermost middle Miocene) are hyaloclastites that appear to be almost entirely of submarine origin, possibly recording the submarine stage of Fuerteventura's shield basalt phase (Figure 2). Microgabbro fragments are present in the hyaloclastites from flow V-3, much of which appear to be the result of shallow-water volcanic activity. This indicates (as may the older trachytic tuff) that part of Fuerteventura was aready an island before its major basaltic shield-forming phase.

3. About 14.5 to 17 m.y. ago (middle Miocene) basaltic subaerial volcanism was fully active, judging from the composition of clasts in debris flow V-1. From the abundance of tachylite, we infer that many lava flows entered the sea at this time. This voluminous near-shore volcanic activity may have been one reason for the supply of particularly abundant detritus that slumped off (?during volcanic earthquakes) to trigger massive debris/grain flows and turbidity currents avalanching southward to the South Canary Island Channel. This near-shore volcanic activity also explains the lack of similar rocks higher in the stratigraphic column.

4. Later events (upper/middle Miocene-Quarternary: 14 to 0.3 m.y.B.P.) were mainly air-fall ashes from explosive eruptions of more differentiated volcanoes of the Canaries which were much less voluminous than the volcanic output during the shield-building stage. Tentatively, three episodes can be distinguished: (a) about 14 to 10 m.y.B.P. (middle to late Miocene) strong explosive activity is recorded producing up to 25-cm-thick ash layers of ?rhyolitic composition and coinciding with "Magmatic Phase I" on Gran Canaria (Lietz and Schmincke, 1975). (b) After a long non-volcanic interval (about 9 to 4.1 m.y.B.P.), a second volcanic activity started about 4 m.y.B.P. (early Pliocene), possibly correlative with the second magmatic phase (Roque Nublo group) on Gran Canaira. (c) The youngest volcanic ashes are 3.3 to $0.3 \mathrm{~m} . \mathrm{y}$. old, and might be derived from Pliocene-Pleistocene trachytic to phonolitic eruptions on Tenerife (see also Arthur et al., this volume).

An alternative interpretation of the succession of volcaniclastic layers at Site 397 would be episodic sedimentologic events acting on a fairly continuous process of island construction, growth, and destruction. This would make many of our speculative interpretations questionable. We do, however, believe that the island's growth is to some degree reflected in the texture and composition of the volcaniclastics as outlined above.

\section{ACKNOWLEDGMENTS}

In writing this paper, we relied heavily on the results of the sedimentologists (M. Arthur, B. Lopatin, F. McCoy, M. Sarnthein, O. Weser) and of the paleontologists of Leg 47A (see Site Chapter, this volume). We are grateful to V. Riech (Hannover) for measuring refractive indexes, photographing thin-sections, and commenting on the zeolites; to H. Rösch (Hannover) for supplying several X-ray diffraction analyses; and to G. Wissman (Hannover) for geophysical information (Figure 1). F. McCoy (Lamont-Doherty Geological Observa-tory) and L. Diester-Haass (Kiel) kindly provided additional samples for our study. The present study was done while the senior author held a grant of the Volkswagen-Stiftung at the University of California, Santa Barbara. R. V. Fisher critically read the manuscript. Our work on DSDP material was supported by the Deutsche Forschungsgemeinschaft.

\section{REFERENCES}

Abdel-Monem, A., Watkins, N. D., and Gast, P. W., 1971. Potassium-Argon ages, volcanic stratigraphy, and geomagnetic polarity history of the Canary Islands: Lanzarote, Fuerteventura, Gran Canaria, and La Gomera, Am. J. Sci., v. 271, p. 490-521.

Bernoulli, D., Fustero, J. M., Hottinger, L., and Renz, O., in press. Mesozoic and early Tertiary sediments and faunas from Fuerteventura (Canary Islands).

Fuster, J. M., Cendrero, A., Gastesi, P., Ibarrola, E., and Ruiz, J. L., 1968. Geology and volcanology of the Canary Islands, Fuerteventura. Inst. "Lucas Mallada," Madrid, Internat. Symposium Volcanology, Tenerife, 1968, Spec. Publ.

Grunau, H. R., Lehner, P., Cleintuar, M. R., Allenbach, P., and Bakker, G., 1975. New radiometric ages and seismic data from Fuerteventura (Canary Islands), Maio (Cape Verde Island), and Sao Tomé (Gulf of Guinea). In Borradaile, G. J., et al. (Eds.). Progress in geodynamics: Amsterdam/New York (North-Holland Publ. Comp.), p. 90118.

Lietz, J. and Schmincke, H. U., 1975. Miocene-Pliocene sea level changes and volcanic phases on Gran Canaria ( $\mathrm{Ca}-$ nary Islands) in the light of new K-Ar ages, Palaeogeography, Palaeoclimatology, Palaeoecology, v. 18, p. $213-$ 239.

MacDougall, I. and Schmincke, H. U., 1977. Geochronology of Gran Canaria Canary Islands: age of shield building volcanism and other magmatic phases, Bull. Volcanologique, v. 40, p. 1-21.

Martini, E., 1976. Cretaceous to Recent calcareous nannoplankton from the central Pacific Ocean. In Schlanger, S. O., Jackson, E. D., et al., Initial Reports of the Deep Sea Drilling Project, v. 33: Washington (U.S. Government Printing Office), p. 383-424. 
Mitchell-Thomé, R. C., 1976. Geology of the middle Atlantic islands: Stuttgart, Berlin (Borntraeger).

Rothe, P., 1968. Mesozoische Flysch-Ablagerungen auf der Kanareninsel Fuerteventura, Geol. Rundschau, v. 58, p. 314-322.

Rothe, P. and Koch R., 1978. Miocene volcanic glass from DSDP Sites 368, 369, and 370. In Lancelot, Y., Seibold, E., et al., Initial Reports of the Deep Sea Drilling Project, v. 41: Washington (U.S. Government Printing Office), p. 1061-1064.
Schmincke, H. U., 1974. Pyroclastic rocks. In Füchtbauer, H. (Ed.), Sediments and sedimentary rocks. I: Stuttgart (Schweizerbart), p. 160-189. 1976. The geology of the Canary Islands. In Kunkel, G. (Ed.), Biogeography and ecology in the Canary Islands: The Hauge (W. Junk), p. 67-184.

Schmincke, H. U. and Staudigel, 1976. Pillow lavas on central and eastern Atlantic islands (La Palma, Gran Canaria, Porto Santo, Santo Maria). Preliminary report, Soc. Géol. France Bull., v. 18, p. 871-883. 
PLATE 1
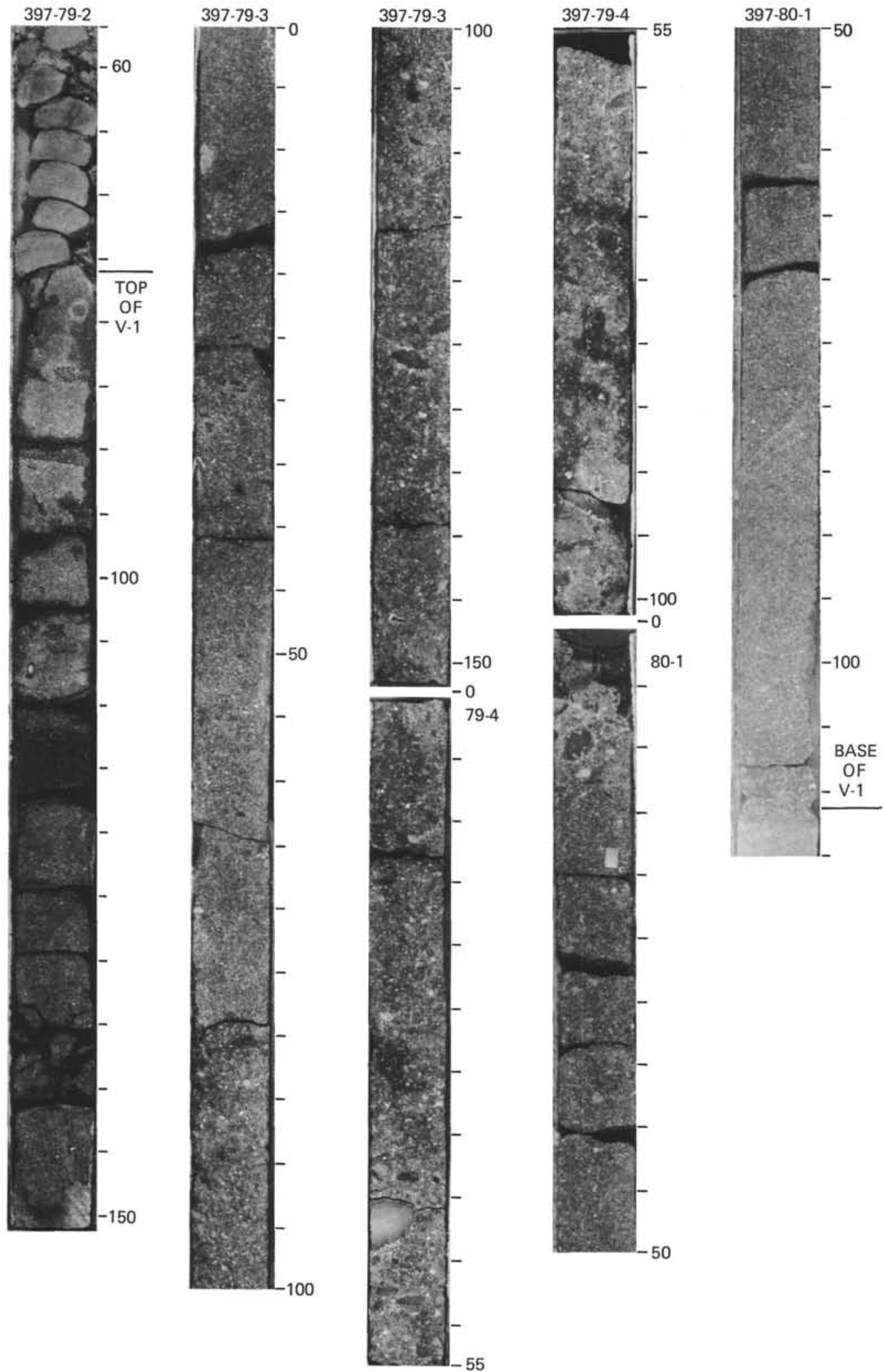

55

Shipboard core photos of volcaniclastic debris flow V-1 (Cores 397-79 and 397-80). Note graded character in upper part (Sections 397-79-2 and 397-79-3); very coarse conglomeratic intercalations near Samples 397-79-4, 40-50 cm and 397-80-1, 0-15 cm; and sharp, graded corse-grained base of flow. For detils see Plate 2. 


\section{PLATE 2}

Shipboard close-up photos of parts of volcaniclastic debris flow V-1 (Cores 397-79 and 397-80). Only top of debris flow (Figure 1) is a medium-grained sandstone; the remainder is a very poorly sorted, coarse sandstone to conglomerate, full of basaltic and sedimentary rock fragments (e.g., large marlstone clast at Sample 397-79-4, 40 $\mathrm{cm}$ ), glass, quartz, and volcanic minerals (clinopyroxenes, altered olivine, feldspar, etc.), all set in a dark brown clayey matrix (see Table 1). Note that the coarsest grain size occurs high above the base of the flow (Figure 3). The basal $4 \mathrm{~cm}$ of the unit (Figure 4) show a light colored marly matrix which was probably churned up by the turbulent flow from the underlying pelagic marlstone. 
PLATE 2
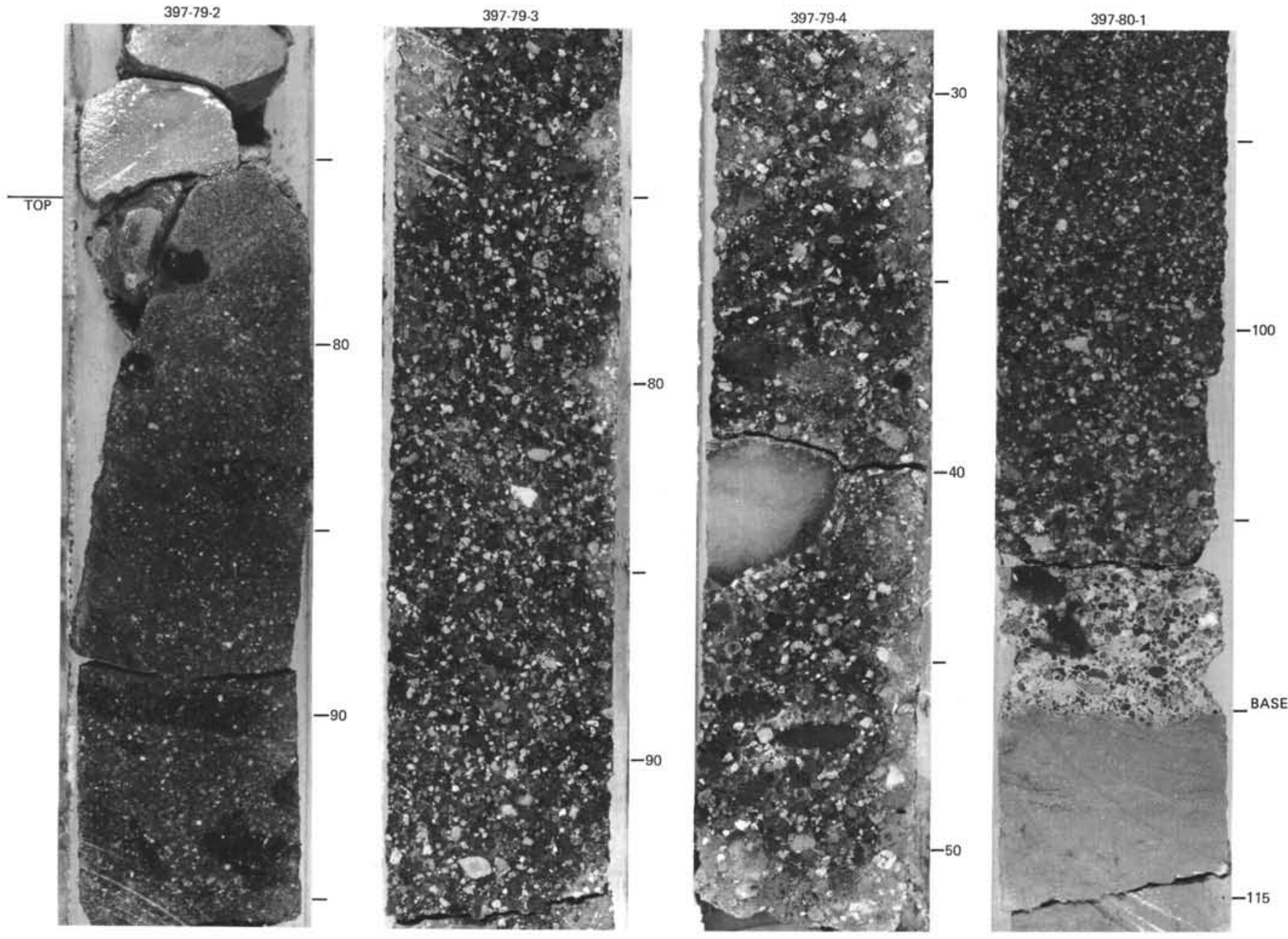
PLATE 3

Photomicrographs of characteristic types of volcaniclastic sandstones (direct projection of thin-section image on large negative).

Figure 1 Sample 397-79-3, 91-93 cm: Volcaniclastic sandstone to conglomerate made up mostly of epiclastic basalt fragments ranging in texture from palagonitized sideromelane (a) to tachylite (b) to crystalline basalt (c) to "microgabbro" (d). Matrix is dominantly montmorillonite.

Figure 2 Sample 397-79-3, 141-143 cm: Volcaniclastic sandstone rich in highly vesicular $\left(b_{1}\right)$ and nonvesicular tachylite $\left(b_{2}\right)$, crystalline basalt $(c)$, and clinopyroxene (cpx) crystals.

Figure 3 Sample 397-79-4, 92-94 cm: Volcaniclastic sandstone with palagonitized, vesicular "sideromelane " shard (a; see also Plate 5, Figure 3), vesicular $\left(\mathrm{b}_{1}\right)$ and non-vesicular tachylite $\left(\mathrm{b}_{2}\right)$, crystalline basalt $(\mathrm{c})$, trachyte fragment (e; see also Plate 4, Figure 4), clinopyroxene (cpx), calcite-replaced olivine (ol), and rounded quartz (q). Large tachylite fragment (top) is shown in more detail in Plate 4 (Figure 2). Note size contrast between tachylite (1 to 4 $\mathrm{mm}$ ), crystalline basalt ( 1 to $2 \mathrm{~mm}$ ), and crystals $(<1 \mathrm{~mm})$. Brown clay matrix is mostly montmorillonite $(\mathrm{mtm})$.

Figure 4 Sample 397-85-3, 77-80 cm: Altered palagonite tuff of unit V-3 showing palagonitized "sideromelane" shards (a; dark, fragmented due to shrinkage cracks?), clinopyroxene (cpx), foraminifers ( $\mathrm{fm}$ ), and many rounded quartz grains (q). Note finer grain size, better sorting, and distinctly different composition of this "hyaloclastite" as compared to the volcaniclastic sandstone of V-1 (this plate, Figures 1 through 3 ). Matrix is mainly montmorillonite. 
PLATE 3
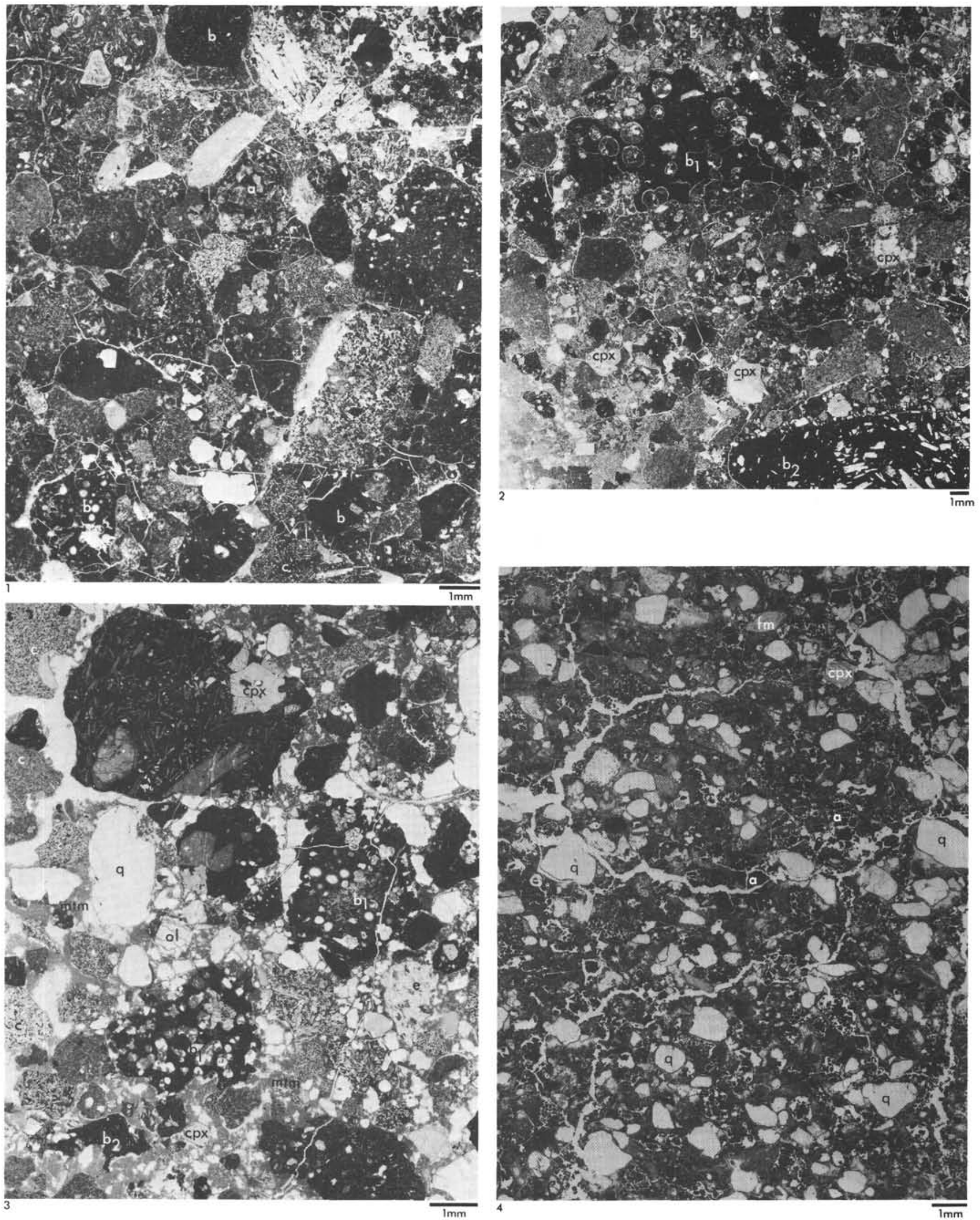


\section{PLATE 4}

Typical fabrics and components of volcaniclastic sandstones Unit V-1, Figures 1 through 4) and hyaloclastites (Unit V-3, Figures 5 and 6).

Figure 1

Figure 2

Figure 3

Figure 4

Figure 5

Figure 6
Sample 397-79-4, 92-94 cm: Crystalline alkali basalt fragment with fresh clinopyroxene phenocryst and microlites, and partly altered plagioclase and titanomagnetite microlites. Mesostasis replaced by clay.

Sample 397-79-4, 92-94 cm; crossed nicols: tachylite rock fragment showing fresh clinopyroxene phenocryst (lower right) with oscillatory zoning and altered plagioclase phenocryst (upper left). Dark ore-rich matrix contains randomly oriented plagioclase microlites.

Sample 397-79-4, 92-94 cm: Moderately fresh mugearite(?) with clinopyroxene phenocrysts; irregular vesicles (filled with clay and carbonate); and flow-banded groundmass of altered plagioclase laths, clinopyroxene, and titanomagnetite.

Sample 397-79-4, 92-94 cm: Trachytic rock fragment consisting dominantly of flow-banded alkali feldspar laths.

Sample 397-84-4, 2-5 cm: Poorly vesiculated, angular, palagonitized "sideromelane" shards from hyaloclastite (Unit V-3). Note planktonic foraminifer (center right) and discoaster (upper right) in brown smectite matrix.

Sample 397-84-4, 2-5 cm: Highly vesicular, palagonitized "sideromelane" shard with flat-ellipsoidal vesicle completely filled with smectite and zeolite (same sample as Figure 5). 
PLATE 4
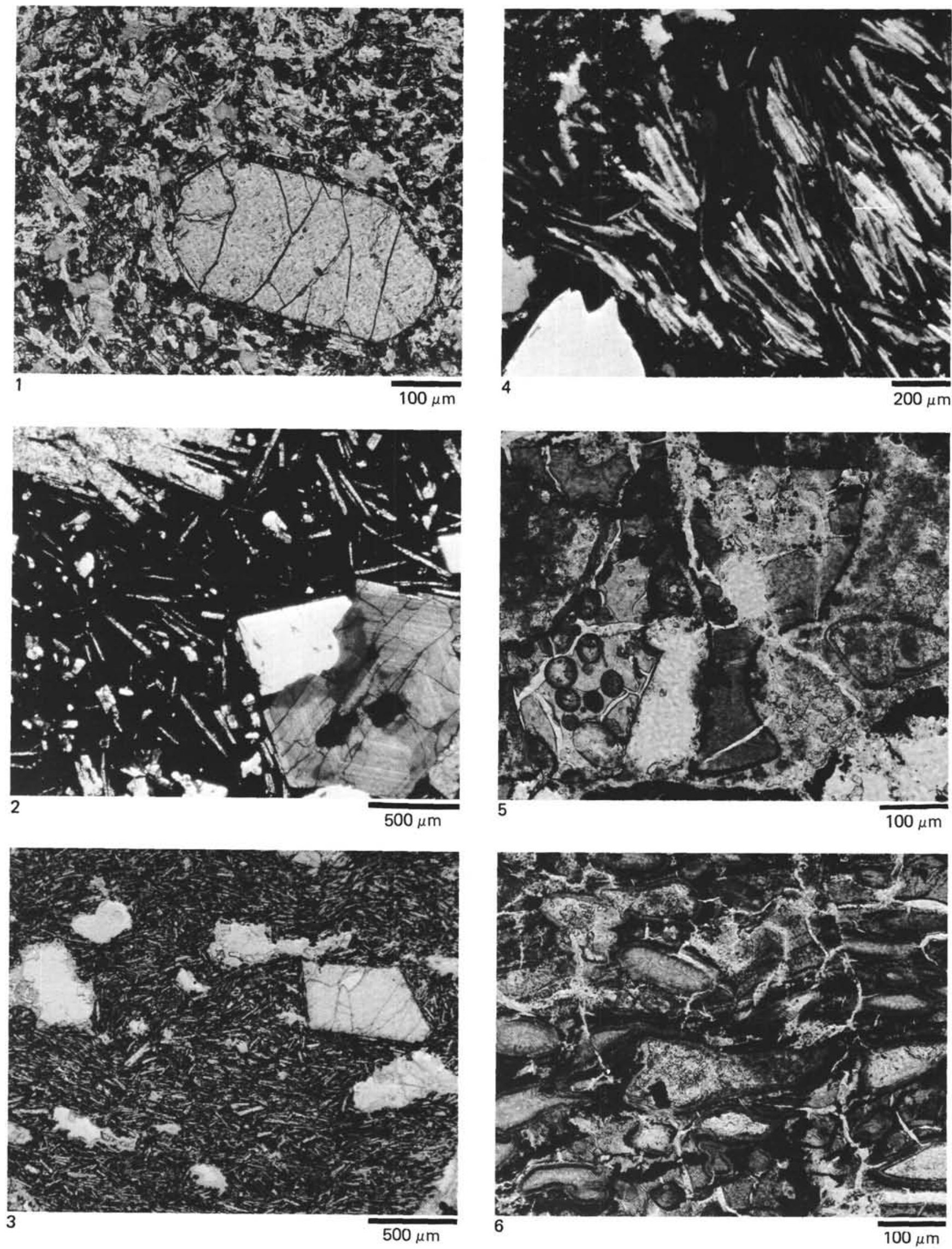
PLATE 5

Glass, secondary minerals, and typical non-volcanic components of volcaniclastic sandstones.

Figure 1 Sample 397A-23-3, 30-33 cm: Montmorillonitized trachytic(?) glass shard, tricuspate and pumiceous glass shards in oldest (19.3 m.y.B.P.) ash layer of Site 397. Most of the other glass shards are completely altered to clay minerals.

Figure 2 Sample 297-79-3, 91-93 cm: Palagonitized sideromelane shard showing olivine(?) phenocryst replaced by smectite (light area) and concentric bands (Ti-phases?) in palagonite. Volcaniclastic debris flow V-1.

Figure 3 Sample 397-79-4, 92-94 cm: Palagonitized, slightly vesicular sideromelane shard showing partially replaced clinpyroxene (lower left and upper right) and completely replaced olivine (?) phenocrysts (upper left) and several generations of clay minerals lining vesicles. Debris flow V-1.

Figure 4 Sample 397-79-3, 141-143 cm: Vesicle in sideromelane shard partially filled with a rim of prismatic zeolites (?phillipsite) and spherulitic or dense phyllosilicate minerals (?chlorite). Remaining pore space is either open (here) or filled with calcite (nearby). Debris flow V-1.

Figure 5 Sample 397-79-3, 21-23 cm: Spherulitic bundles of zeolites (?phillipsite) filling interstices of greenish brown ?smectite matrix.

Figure 6 Sample 397-78-4, 39-43 cm; crossed nicols: Large metaquartzite fragment (elongated quartz grains with crenulated borders) in a pebbly mudstone which also contains some volcanic rock fragments (V-1a).

Figure 7 Sample 397-78-4, 39-43 cm: Oncoid overgrown by coralline algae (?"Lithothamnium") and ?bryozoan (same debris flow as in Figure 6). Dark interior of oncoid shows concentric growth rings.

Figure $8 \quad$ Sample $397-79-4,37-40 \mathrm{~cm}$ : Coralline algal fragment (?Lithothamnium) in volcaniclastic debris flow V-1 indicating derivation from the photic littoral zone. Planktonic foraminifer at lower right. 


\section{PLATE 5}
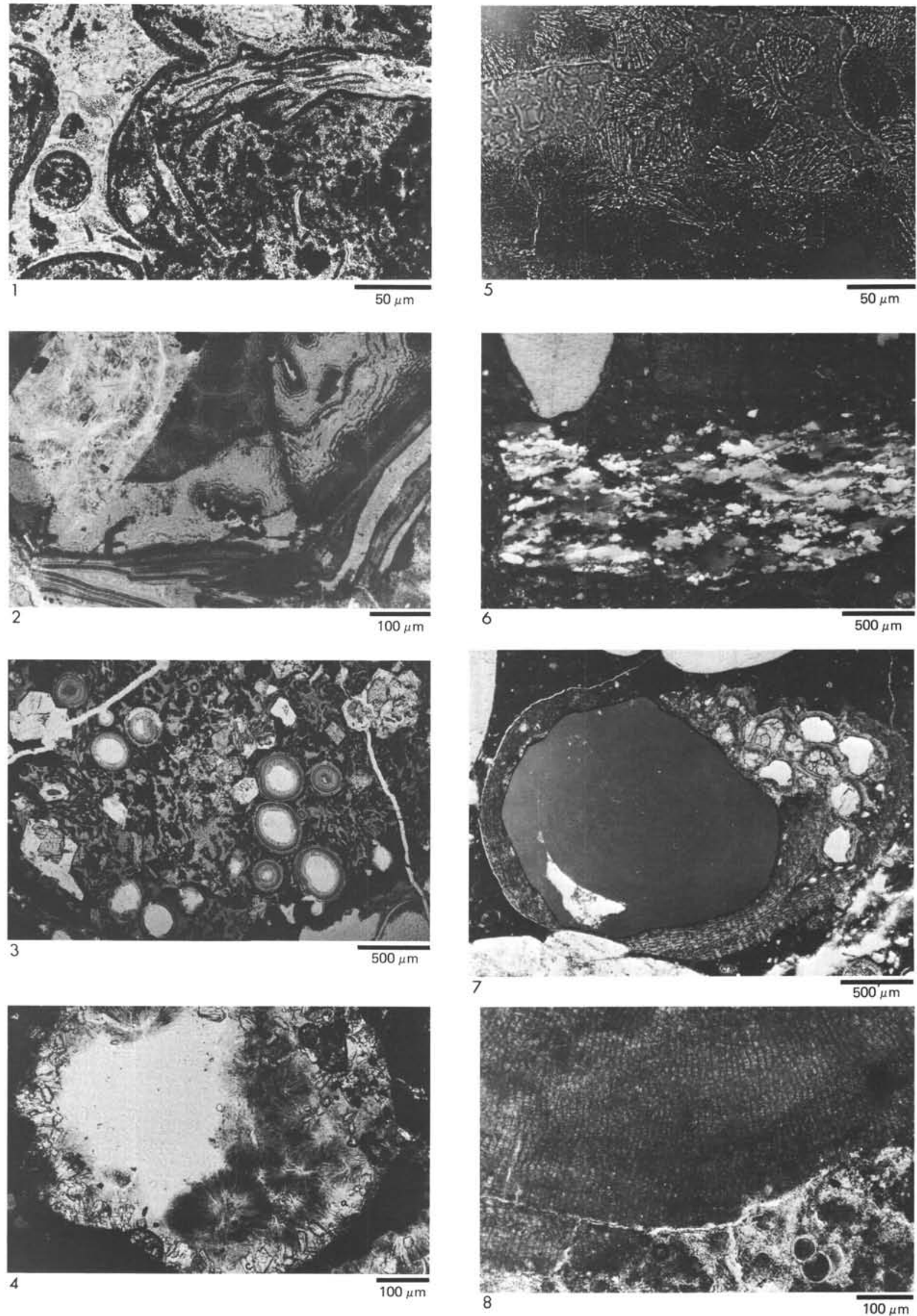